\title{
Life in Kellis: Society and Religion in an Oasis Town
}

The Manichaeans visible in the House 1-3 material moved through a specific geographical and social landscape, that of Roman Kellis and its oasis surroundings, the Dakhleh Oasis in western Egypt. Excavations of the last few decades have provided a wealth of information about conditions in Dakhleh in the Roman period: its natural environment, population, government, and economic life. These factors are preconditions for understanding the villagers and their social world, and moreover affected the way Manichaeism came to be established here. They are the subject of the present chapter.

First, let us briefly look at the spread of Manichaeism in Egypt before it ventured out to the Oasis. Its history here is comparatively well-documented. Manichaean narratives from Turfan indicate that an early disciple, Adda, reached Alexandria during Mani's own lifetime, between $c .242-270 .{ }^{1}$ Mani is said to have ordered Adda to stay there and preach, and sent him copies of his writings. Other sources corroborate a Manichaean presence in Egypt by the late third century. A Neoplatonist philosopher, Alexander of Lycopolis, wrote a treatise against the Manichaeans c.30o, naming the first missionaries in his locality as Pappos and Thomas. ${ }^{2}$ Another early witness is a papyrus letter ascribed to Theonas, bishop of Alexandria (c.28o-30o), denouncing Manichaean missionaries in harsh words - female Elect, in particular. Roman authorities, too, took note of their arrival. An edict of Emperor Diocletian, promulgated in Alexandria in $3 \mathrm{O} 2$ and addressed to the prefect of North Africa,

1 Michel Tardieu, 'Les manichéens en Égypte', Bulletin de la Société Française d'Égyptologie 94 (1982), 27-40; Ludwig Koenen, 'Manichäische Mission und Klöster in Äegypten', in Das Römisch-Byzantinische Ägypten: Akten des internationalen Symposions 26.-30. September 1978 in Trier, ed. Günter Grimm (Mainz: Philipp von Zabern, 1983). Van den Berg (Biblical Argument, 35) argues that 'it is most probable that Addas started his mission early, about 243.'

2 He may have been in Alexandria at this point. Pappos could well be another name for Addā; see van den Berg, Biblical Argument, 21-23. Thomas is generally taken as the author of the 'Psalms of Thomas' in the Medinet Madi Psalm-book, although Jürgen Tübach has argued, based on the Mandaean affinities of these psalms, that the disciple Thomas was fictive and that the Thomas-psalms originally belonged to the Mandaean community. Jürgen Tubach, 'Die Thomas-Psalmen und der Mani-Jünger Thomas', in Il Manicheismo. Nuove prospettive della ricera, ed. A. van Tongerloo and L. Cirillo (Turnhout: Brepols, 2005).

(C) HÅKON FIANE TEIGEN, 2021 | DOI:10.1163/9789004459779_003

This is an open access chapter distributed under the terms of the CC BY-NC-ND 4 4 o license. Teigen - 9789004459779 
decreed harsh punishments for Manichaeans in the Roman Empire. ${ }^{3}$ But the movement grew in strength despite invectives and persecution, drawing ire from Christian leaders. Two authorities of the mid-fourth century, Serapion of Thmuis and Didymus the Blind, polemicised against the sect. Athanasius of Alexandria targeted Manichaeans, alongside other 'heretics', in his 39th Festal Letter (dated 367 ). ${ }^{4}$ Yet, the Coptic patriarch Eutychius of Alexandria (fl. ninthtenth century) claimed that they were so widespread at the time of his distant predecessor, Timothy $(c .38 \mathrm{O}-85 \mathrm{CE})$, that Timothy made monks undergo food-tests in order to root out Manichaeans among them. ${ }^{5}$ Upper Egypt, in particular, has been seen as a Manichaean stronghold. ${ }^{6}$ Thus, Jozef Vergote, based on earlier suggestions by Michel Tardieu and Ludwig Koenen, proposed two concurrent routes of dissemination: the mission of Adda through Alexandria, and one through Aelana (Aqaba) on the Red Sea, down to the ports of Upper Egypt. ${ }^{7}$ At any rate, it was in Upper Egypt, from cities such as Antinoopolis, Lycopolis, and Panopolis, that the Manichaeans found roads leading from the Nile Valley to the western oases.

The Dakhleh Oasis is one of five oases constituting the westernmost inhabited parts of Egypt, surrounded by the Sahara Desert. ${ }^{8}$ They were all settled in pre-dynastic times, and have been inhabited continuously since. In antiquity, Dakhleh was often grouped together with the neighbouring oasis to its east,

3 Lieu, Manichaeism in the Roman Empire, 91-94.

4 See David Brakke, 'A New Fragment of Athanasius's Thirty-Ninth Festal Letter: Heresy, Apocrypha, and the Canon', Harvard Theological Review 103, no. 1 (2010).

5 Lieu, Manichaeism in the Roman Empire, 146.

6 Samuel N. C. Lieu, Manichaeism in Mesopotamia and the Roman East (Leiden: Brill, 1994), 92-93; Siegfried G. Richter, 'Manichaeism and Gnosticism in the Panopolitan Region between Lykopolis and Nag Hammadi', in Christianity and Monasticism in Upper Egypt, ed. Gabra Gawdat and Hany N. Takla (Cairo: The American University in Cairo, 2008).

7 Tardieu, 'Les manichéens en Égypte' and Koenen, 'Manichäische Klöster', 96-98. See J.Vergote, 'L'expansion du Manichéisme en Égypte', in After Chalcedon: Studies in Theology and Church History, ed. C. Laga, J. A. Munitiz, and L. van Rompay (Leuven: Orientala Lovaniensia Analecta, 1985). It has, perhaps, some support in its ability to explain differences in terminology between different Coptic Manichaean texts, as argued by Paul van Lindt, The Names of Manichaean Mythological Figures: A Comparative Study on Terminology in the Coptic Sources (Wiesbaden: Otto Harrassowitz, 1992), 221-22. Van den Berg (Biblical Argument, 37) regards the southern route as the most probable one.

8 The others are Farafra, Bahariya, the Ammonite (modern Siwa), and Dakhleh's neighbour, Khargeh Oasis. 
Khargeh, under the umbrella term the 'Great Oasis' (oasis magna), or simply 'the Oasis'. Herodotus referred to the Great Oasis as 'the island of the blissful', and it had a reputation for being rich and fertile, as related by Strabo and by Olympidorus of Thebes. ${ }^{9}$ The latter ( $f$ l. mid-fifth century CE) is one of the few ancient historians from Upper Egypt itself; he claimed to have visited the Great Oasis itself. He distinguished between the 'outer' ( $\dot{\xi} \xi \omega \tau \varepsilon \dot{\varepsilon} \rho)$ and the 'inner' ( $\dot{\sigma} \sigma \tau \tau \dot{\varepsilon} \rho \omega$ ) oasis: terms which, as Guy Wagner noted, correspond exactly to the current Arabic terms 'Khargeh' and 'Dakhleh.'10 The reference point for these designations is the desert. Dakhleh is 'innermost', towards the desert, furthermost from the Nile Valley. Being larger and closer to the Nile Valley, Khargeh was the more important of the two. Well-travelled, if difficult, roads led here from the major Valley cities of Abydos and Lycopolis. ${ }^{11}$ According to Strabo, the journey from Abydos to the Great Oasis - meaning probably Khargeh took seven days. ${ }^{12}$ The Dakhleh Oasis lay westward, beyond another stretch of desert - further into the desert, as its name implies, although roads also continued northward from Dakhleh, eventually reaching the Mediterranean coast. A long desert road, faster but less convenient, went directly from Lycopolis to Dakhleh. It took between six and ten days by donkey, a bit less by camel..$^{13}$ Travel could be a challenge. A Roman official, travelling from Khargeh to Dakhleh in the late fourth century, described a journey of 'four days and nights

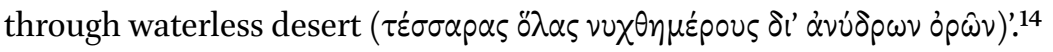

The climate of the Great Oasis is indeed extreme: harsh sunlight, sandcarrying winds at times rising to storms, and long periods of heat relieved only by rare rainstorms. ${ }^{15}$ In such an environment, human settlements only

9 See Guy Wagner, Les Oasis d'Égypte: à l'époque grecque, romaine et byzantine d'après les documents grecs (Paris: Institut français d'Archéologie orientale du Caire, 1987), 113-14.

$10 \quad$ Ibid., 131 n.6.

11 See Alan Roe, “The Old "Darb al Arbein" Caravan Route and Kharga Oasis in Antiquity', Journal of the American Research Center in Egypt 42 (2005).

12 Wagner, Les Oasis d'Égypte, 143.

13 For the journey, P.Kellis $V$, 12. Herbert E. Winlock, travelling by camel in 1908, reportedly spent eight days on the road from Assiut (Lycopolis) to Dakhleh; ibid., 63. See also Bagnall and Aravecchia, 'Economy and Society', 168-70.

14 M.Chr. 78 (ll.6-7). The author is writing to a superior, and some exaggeration is perhaps to be allowed for but is probably slight. Two roads reached Dakhleh from Khargeh: a level - but waterless - one to the south, and a longer, more difficult one to the north, but with water and some comfort available at the 'mini-oasis' Ain Amour, where a Roman fort has been excavated. Wagner, Les Oasis d'Égypte, 144-45; Robert B. Jackson, At Empire's Edge: Exploring Rome's Egyptian Frontier (New Haven: Yale University Press, 2002), 198-200.

15 Measurements put rainfall at o to imm per year. Warm summers can see the temperature remain at over $40^{\circ} \mathrm{C}$ for long periods, while it can change rapidly in winter, from $\mathrm{O}^{\circ}-2^{\circ} \mathrm{C}$ 


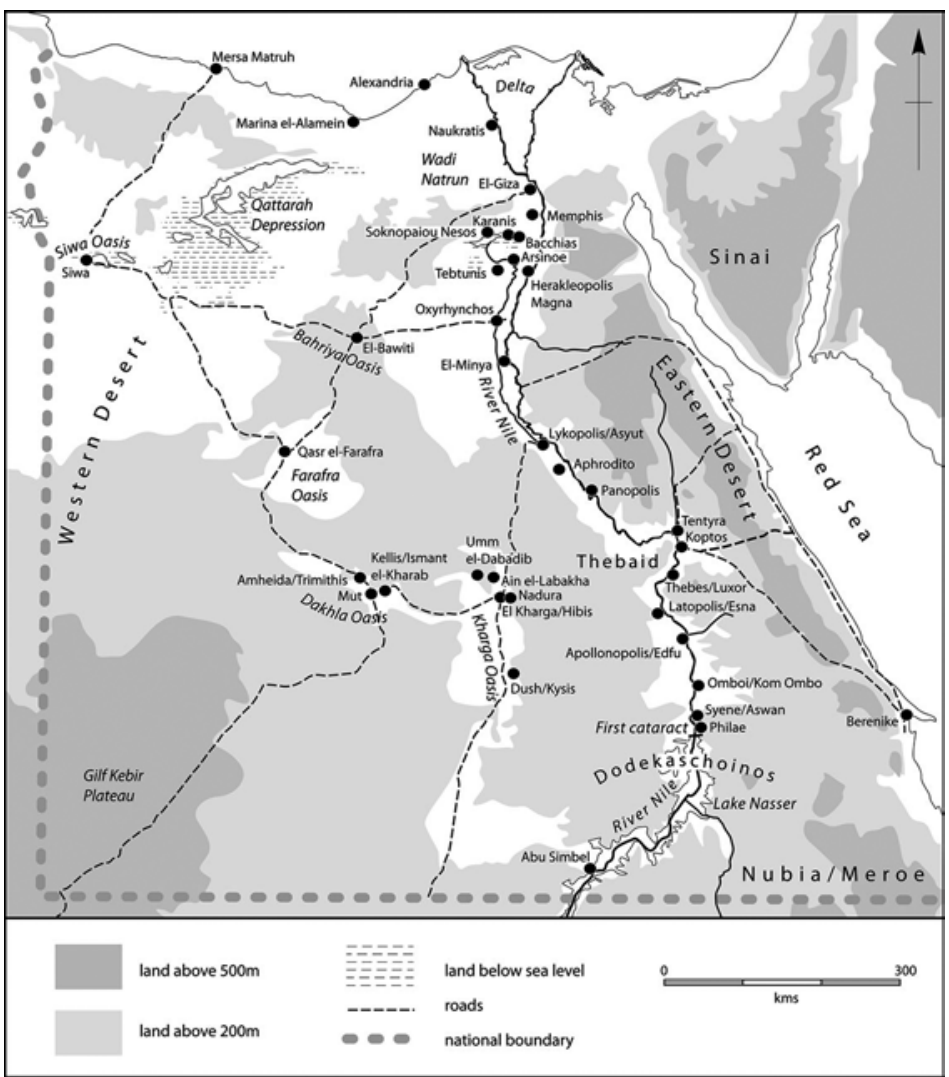

FIGURE 1 Map of Egypt

CREDIT: ANNA L. BOOZER (DRAWN BY M. MATHEWS)

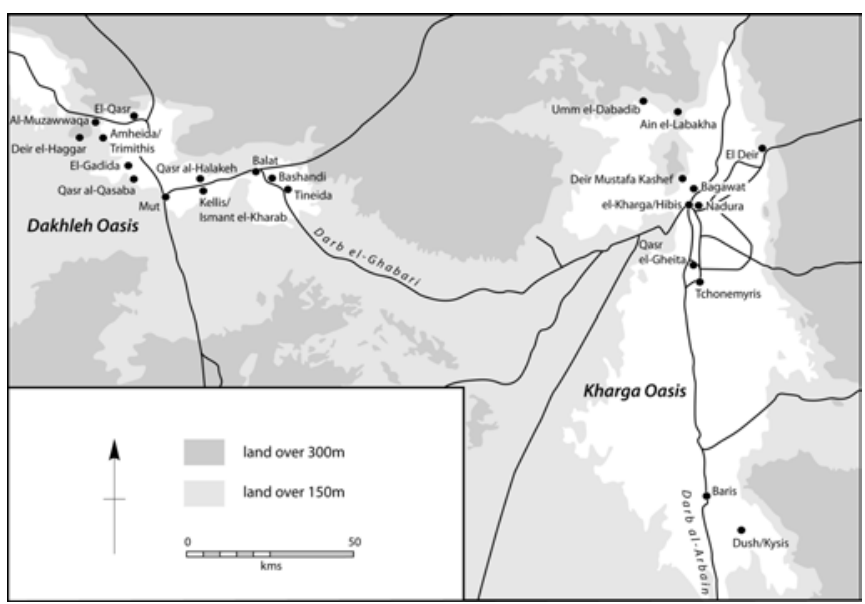

Figure 2 Map of the 'Great Oasis'

CREDIT: ANNA L. BOOZER (DRAWN BY M. MATHEWS) 
bloom under very particular circumstances. In the oases, settled life is made possible by a large, underground aquifer layer. In some places, groundwater gushes forth in natural springs, but for the most part reservoirs, wells, and canals must be constructed in order to irrigate the land. Oasis settlements grew up around clusters of such water sources. The control of wells was a contentious issue already in Pharaonic times. According to Olympiodorus, wells were constructed through communal effort, although right of usage seems to have been strictly regulated and privately owned, as attested to by the numerous occurrences of well-tags among the ostraka with the formula 'well of [name]'.16

As the oases were not linked to the Nile floods, human activity here took on a distinct character vis-à-vis the rest of Egypt. Bagnall has argued that Oasite society in the Roman era must have been characterised by a smaller segment of independent peasants than Egypt in general. ${ }^{17}$ Only the very wealthy could have financed well construction, and so the agricultural sector came to be

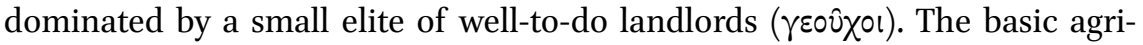
cultural product was grain, wheat, barley, and millet, while fruit crops were of great economic importance. By Roman times, they included grapes, olives, and dates, cultivated alongside various other products such as cotton, jujubes, honey, vegetables, and possibly sesame and cumin. Cotton may have been of particular importance to the Great Oasis. ${ }^{18}$ The introduction of new lifting devices and techniques in Achaemenid, Ptolemaic, and Roman times allowed for more intensive irrigation. ${ }^{19}$ This may have facilitated a growth in population, helped by migration from the Nile Valley. The many Roman-era archaeological sites show some population growth in Dakhleh in the first few centuries CE. In fact, Dakhleh appears to have reached its pre-modern population zenith under the Romans. ${ }^{20}$ Its major population centres were Mothis, its

in the morning to $20^{\circ}-25^{\circ} \mathrm{C}$ by midday. Anna L. Boozer, 'The Social Impact of Trade and Migration: The Western Desert in Pharaonic and Post-Pharaonic Egypt', ed. Christina Riggs, Oxford Handbooks in Archaeology Online (Oxford: Oxford University Press, 2015), 5.

16 Wagner, Les Oasis d'Égypte, 280-81; Anthony J. Mills, 'Pharaonic Egyptians in the Dakhleh Oasis', in Reports from the Survey of the Dakhleh Oasis 1977-1987, ed. Charles S. Churcher and A. J. Mills (Oxford: Oxbow, 1999), 175-76. For well-tags from Roman Trimithis, see Roger S. Bagnall and Giovanni Ruffini, Amheida I: Ostraka from Trimithis. Texts from the 2004-2007 Seasons. (New York: New York University Press, 2012).

17 Bagnall and Aravecchia, 'Economy and Society'.

18 Wagner, Les Oasis d'Égypte, 284-301; P.Kellis IV, 36-46; Ursula Thanheiser, 'Roman Agriculture and Gardening in Egypt as Seen from Kellis', in Dakhleh Oasis Project: Preliminary Reports on the 1994-1995 to 1998-1999 Field Seasons, ed. Colin A. Hope and Gillian Bowen (Oxford: Oxbow, 2002). For the importance of cotton, see Bagnall and Aravecchia, 'Economy and Society', 154-55.

19 Mills, 'Pharaonic Egyptians', $175^{-76 .}$

20 Boozer, 'The Social Impact', 15. Dakhleh was perhaps more populated in Roman than in modern times, see J. E. Molto, 'Bio-Archaeological Research of Kellis 2. An Overview', in 
capital, and Trimithis, an urban centre that at least by the early fourth century had also received status as a polis. Anna L. Boozer has estimated Trimithis' population at $c .25$ ooo in this period. A tax assessment from Hermopolis (dated c.368) indicates that Mothis was still larger, perhaps by as much as one third. ${ }^{21}$

While Olympidorus, in the fifth century, still considered the 'Great Oasis' prosperous, contemporary Christian authors such as Gregorius of Nazanzius, Asterios, and Zosimus held a less rosy view: they emphasised its extreme weather conditions and lack of water. ${ }^{22}$ Whether this reflected deteriorating conditions since Strabo (and consequently an anachronism by Olympiodorus), or a conflation of oasis and desert by the Christians (and perhaps a desire to stress the suffering of co-believers who were exiled there), is difficult to determine. Recent archaeological surveys and excavations have found a change in settlement patterns in the late fourth and fifth century, including the abandonment of some important sites, perhaps suggesting that conditions had indeed gotten worse. ${ }^{23}$

The Great Oasis stood out from Egypt, not only with respect to climate but with respect to cultural differences as well. Roman authorities found it relevant (at least at times) to distinguish between 'Oasites' and other 'Egyptians.'24 That a distinct 'Oasite-ness' was felt by the local people themselves is indicated by Coptic documents from Kellis, where travelling to the Nile Valley is often seen as going 'to Egypt'. It may furthermore be reflected in the fate of the god Seth. This god, once important in Upper Egypt, was largely suppressed by Egyptian authorities from the 25 th dynasty $(760-656$ вСЕ) onwards in the Nile Valley, but temples of Seth continued to operate in Dakhleh and Khargeh into Roman times. ${ }^{25} \mathrm{~A}$ certain frontier mentality may have characterised the inhabitants.

Dakhleh Oasis Project: Preliminary Reports on the 1994-1995 to 1998-1999 Field Seasons, ed. Colin A. Hope; Gillian E. Bowen (Oxford: Oxbow, 2002), 239.

P.Kellis IV, 73, n.42. Anna L. Boozer, 'Urban Change at Late Roman Trimithis (Dakhleh Oasis, Egypt)', in Egypt in the First Millenium AD: Perspectives from New Fieldwork, ed. Elisabeth R. O'Connell (Leuven-Paris-Walpole: Peeters, 2014), 29.

22 Wagner, Les Oasis d'Égypte, 116-19.

23 Most notably Trimithis and Kellis itself. Roger S. Bagnall and Olaf Kaper, 'Introduction', in An Oasis City, ed. Roger S. Bagnall, et al. (New York: New York University Press, 2015), 23-24. For a tentative explanation, see Roger S. Bagnall and Nicola Aravecchia, 'Economy and Society in the Roman Oasis', in An Oasis City, ed. Roger S. Bagnall, et al. (New York: New York University Press, 2015), 188-89.

24 Wagner, Les Oasis d'Égypte, 214-15. For an examination of the tensions between Nile and Oasis, and the Roman construction of Oasite otherness, see Anna L. Boozer, 'Frontiers and Borderlands in Imperial Perspectives: Exploring Rome's Egyptian Frontier', American Journal of Archaeology 117, no. 2 (2013).

25 See Olaf E. Kaper, Temples and Gods in Roman Dakhleh: Studies in the Indigenous Cults of an Egyptian Oasis (Groningen: privately published, 1997), 84-85. 
The Great Oasis was used by Roman authorities for exiling criminals (and, in the fourth and fifth centuries, religious 'trouble-makers'), perhaps increasing the sense of distance from Egypt at large. Since Old Kingdom times, the areas around the settled parts of the Great Oasis had been inhabited by pastoral nomads, called 'Libyans' or 'Blemmyes', adding to its social and ethnic diversity. While conflict occasionally erupted between nomads and settled areas - the 'Blemmyes' are said to have pillaged Hibis in 373 - peaceful co-existence would have been the norm. ${ }^{26}$

Its distinctiveness should not be exaggerated, either. Economic growth would have been helped by (and in turn attracted) settlers from other parts of Egypt. Conversely, the Oasites had an interest in goods, artefacts, and cultural trends from the Valley. Graeco-Roman artistic styles, architecture, and literature have all left traces in Dakhleh. Christianity was established here by the early fourth century; churches have been found even in small hamlets such as Ain el-Gedida (probably ancient Pmoun Berri) and Ain es-Sabil. ${ }^{27}$ The appearance of Manichaeans here in the same period, not long after the initial arrival of the movement in Egypt, has to be seen in this light.

\subsection{Local Government}

The Roman presence in the Great Oasis in the late Roman period was extensive. The military provided an especially visible manifestation of Roman power: in Dakhleh, a castrum was built in the late third century near Trimithis, at what is today al-Qasr, and equipped with an equestrian military detachment, the Ala I Quadorum. ${ }^{28}$ For the most part, however, the Romans relied on a system of civilian officials, drawn from local urban elites and village property holders. As we shall see, many such officials make their appearance in the House 1-3 material, providing evidence for the inhabitants' links to different hubs of power in the imperial structure. This structure therefore needs to be presented in some detail.

26 Wagner, Les Oasis d'Égypte, 394-40o; Boozer, 'Frontiers and Borderlands', 278-82.

27 Nicola Aravecchia, 'Christians of the Western Desert in Late Antiquity: The FourthCentury Church Complex of Ain el-Gedida, Upper Egypt' (Ph.D., University of Minnesota, 2009), 257; Nicola Aravecchia, Roger S. Bagnall, and Raffaella Cribiore, 'Christianity at Trimithis and in the Dakhla Oasis', in An Oasis City, ed. Roger S. Bagnall, et al. (New York: New York University Press, 2015).

28 Paul Kucera, 'Al-Qasr: The Roman castrum of Dakhleh Oasis', in The Oasis Papers 6: Proceedings of the Sixth International Conference of the Dakhleh Oasis Project ed. Paula Davoli, Roger S. Bagnall, Colin A. Hope (Oxford: Oxbow, 2012), 312. Other units may have been present; Rodney Ast and Roger S. Bagnall, 'New Evidence for the Roman Garrison of Trimithis', Tyche 30 (2015). 
Up until the fourth century, the Great Oasis was a single administrative unit - a municipality, called a nome - consisting of both Khargeh and Dakhleh, centred on the city of Hibis in Khargeh - although unusually for a nome, the 'Great Oasis' had several urban centres with status as polis. ${ }^{29}$ The most important civilian representative of the Roman government was the municipal governor or strategos ( $\sigma \tau \rho \tau \tau \eta \gamma o ́ \varsigma)$, appointed by the prefect in Alexandria. The strategos supervised nome government: he controlled the public records and adjudicated conflicts, which elsewhere in the Empire was handled by the local city council $(\beta \circ \nu \lambda \eta \dot{)})$. Such city councils were formally introduced to Egypt

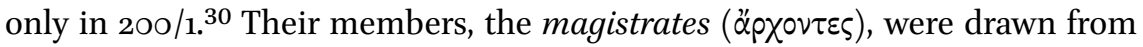
among wealthy and respected local notables, by scholars often referred to as the curial class. Magistrates were responsible for organising and financing public services, like keeping the peace, managing taxation, or arranging festivals.

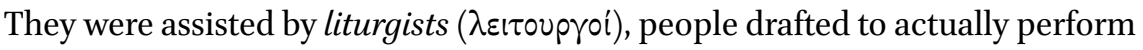
services such as guard duty or tax collection. Magistracies and liturgies were usually restricted to half a year or one year's service, although by the fourth century the same person could serve several terms. ${ }^{31}$ Generally, liturgies and, by the fourth century, magistracies were considered burdens from which many sought to be exempted.

Like the rest of the Empire, Egypt saw a large-scale administrative reorganisation in the late third and early fourth century. ${ }^{32}$ Upper Egypt was made into a separate province, the Thebais, with its own governor seated in Antinoopolis. ${ }^{33}$ A new office, the curator civitatis or logistes ( as chief civilian representative in the nomes, while the strategos was demoted

29 Roger S. Bagnall and Giovanni R. Ruffini, 'Civic Life in Fourth-Century Trimithis. Two Ostraka from the 2004 Excavations', Zeitschrift für Papyrologie und Epigraphik 149 (2004): $143-44$.

30 Although some form of local civic bodies also existed before this date; Alan K. Bowman and Dominic W. Rathbone, 'Cities and Administration in Roman Egypt', The Journal of Roman Studies 82 (1992): 120-27.

31 Naphtali Lewis, The Compulsory Public Services of Roman Egypt, 2nd ed. (Firenze: Edizioni Gonnelli, 1997), 65; 76. For repeated service, see Roger S. Bagnall, 'Property Holdings of Liturgists in Fourth-Century Karanis', The Bulletin of the American Society of Papyrologists 15 , no. 1/2 (1978).

32 For a summary, see Roger S. Bagnall, Egypt in Late Antiquity (Princeton, NJ: Princeton University Press, 1993), 59-67; Alan K. Bowman, 'Egypt from Septimus Severus to the Death of Constantine', in The Cambridge Ancient History, ed. Alan K. Bowman, Averil Cameron, and Peter Garnsey (Cambridge: Cambridge University Press, 2005).

33 Various rearrangements were made in the course of the fourth century. See Bagnall, Egypt in Late Antiquity, 63-64; Alan K. Bowman, Egypt after the Pharaohs 332 BC-AD 642: From Alexander to the Arab Conquest (Berkeley: University of California Press, 1986), 81-84. 
and renamed exactor civitatis. ${ }^{34}$ Instead of being outside appointees, both offices came to be drawn from among the local notables. In the 'Great Oasis', Dakhleh was made into a nome at this time, with Mothis as its capital. It became known as the 'Mothite Nome', while Khargeh was the 'Hibite Nome', both subjected to the governor of the Thebais. ${ }^{35}$ Yet, despite this division, it seems that the logistes and the exactor retained overall responsibility for both, and so the Great Oasis remained administratively quite centralised, a point to which we return below. The city councils, too, saw big changes. Many traditional magistracies disappeared. The councils were made to take increased part in administration of the surrounding countryside. The rural districts into which nomes were subdivided ( $p a g i$ ) now came under the supervision of new liturgical officials, drawn from the curial class, the praepositi pagi. The Great Oasis likely had peculiar arrangements also in this regard. ${ }^{36}$ Another new magistrate, the riparius, oversaw law and order. ${ }^{37}$ One such riparius, who doubled as strategos/exactor, was of local significance in Kellis - perhaps particularly to the Manichaean community, as we shall see.

The villages that dotted the countryside had their own liturgical officials, locals who were responsible for maintaining order, keeping records, and collecting taxes, overseen by the praepositus. ${ }^{38}$ Liturgists were appointed from among villagers of a certain financial standing, to ensure that services were performed and taxes paid. Like other liturgies, service was compulsory, and villagers served at their own cost and responsibility - and, like their urban counterparts, many sought to avoid them. Local offices included the 'village head' or komarch ( $x \dot{\omega} \mu \alpha p \times \circ \varsigma)$, an important office that remained popular despite the

34 Brinley R. Rees, 'The curator civitatis in Egypt', The Journal of Juristic Papyrology 7-8 (19531954): 98-104; Lewis, Compulsory Public Services, 82. The term 'strategos' remained in use in the fourth century; J. David Thomas, 'Strategos and Exactor in the Fourth Century: One Office or Two?', Chronique d'Égypte 70, no. 139-140 (1995).

35 Bagnall suggests $307 / 8$ as the year of division, P.Kellis IV, 73; see also Worp, 'Short Texts', 345-46.

36 Bagnall and Ruffini propose that, due to the lack of separate logistai in the Oasis cities, the praepositus 'may have functioned as a kind of mini-logistes on the spot.' Roger S. Bagnall and Giovanni Ruffini, Amheida I. Ostraka from Trimithis. Texts from the 2004-2007 Seasons (New York: New York University Press, 2012), 46.

37 In conjunction with the 'city advocate' or defensor civitatis ( $\sigma \dot{v} v \delta(x \circ \varsigma$, है $x \delta(x \circ \varsigma)$. See Bagnall, Egypt in Late Antiquity, 61; Sofia Torallas Tovar, 'The Police in Byzantine Egypt: The Hierarchy in the Papyri from the Fourth to the Seventh Century', in Current Research in Egyptology, ed. Christina Riggs and A. McDonald (Oxford: 200o), 115-16; Brinley R. Rees, 'The defensor civitatis in Egypt', The Journal of Juristic Papyrology 6 (1952).

38 Village liturgists were originally appointed by the strategos, transferred to the praepositus in the fourth century. Lewis, Compulsory Public Services, 65-66, 82. The strategos/exactor still had some function related to liturgies in Dakhleh; see P.Kellis I Gr. 23. 


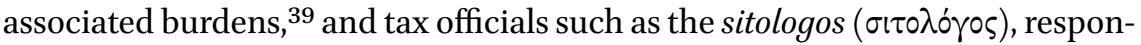
sible for taxes in wheat and barley, and the apaitetes ( $\dot{\alpha} \pi \alpha i \tau \eta \tau \dot{\eta} \varsigma)$, for taxes on other goods and trades. This system of urban and rural officials drawn from local elites was intended to ensure an administration that required relatively little interference by the Roman government.

\section{3 The Village of Kellis}

Ismant el-Kharab, ancient Kellis, lies to the east of Mothis and far southeast of Trimithis, and is today bounded by two intersecting wadis. The village seems to have been a relatively new foundation, occupied from around the first to the end of the fourth century. ${ }^{40}$ Unlike most Egyptian villages, ${ }^{41}$ it had recognisable public buildings such as a bathhouse and nymphaeum. It covered an area of $1050 x 650 \mathrm{~m}\left(68.3 \mathrm{~m}^{2}\right)$, which excavators have divided into four primary sectors: Area A, B, C and D. A short tour of these can give us a feel for its layout.

Area $\mathrm{D}$ was the initial focal point of the village. It was dominated by the large temple complex referred to as the Main Temple, dedicated to the divine triad of Tutu, Neith and Tapshai - the 'great gods' of Kellis. The datable material from the temple area covers the entire lifespan of the village, although the temple itself went out of use at some point in the early-to-mid fourth century. Around the same time, a small church was built in the north-western corner of the temple-area. Northeast of the temple lies Area B. It has been suggested that a large complex here, $\mathrm{B} / 1 / 1$, had a civic function, although recent finds are more suggestive of a group of discrete, elite housing units. ${ }^{42}$ Parts of it seems to have been converted into stables in the fourth century. A large and richly painted residence, $B / 3 / 1$, located at the northern end of Area B, showcases the

39 Diana Delia and Evan Haley, 'Agreement Concerning Succession to a Komarchy', The Bulletin of the American Society of Papyrologists 20, no. 1-2 (1983): 43.

40 See Colin A. Hope, 'Observations on the Dating of the Occupation at Ismant el-Kharab', in The Oasis Papers: Proceedings of the First International Symposium of the Dakhleh Oasis Project, ed. Charles A. Marlow; Anthony J. Mills (Oxford: Oxbow, 2001).

41 Bagnall, Egypt in Late Antiquity, 112-14; James G. Keenan, 'The Aphrodite Papyri and Village Life in Byzantine Egypt', Bulletin de la Société d'archéologie copte 26 (1984); Peter van Minnen, 'House-to-House Enquiries: An Interdiciplinary Approach to Roman Karanis', Zeitschrift für Papyrologie und Epigraphik 100 (1994).

42 Colin A. Hope, 'The Roman-Period Houses of Kellis in Egypt's Dakhleh Oasis', in Housing and Habitat in the Ancient Mediterranean: Cultural and Environmental Responses, ed. A. A. Di Castro, Colin A. Hope, and B. E. Parr (Leuven: Peeters, 2015), 201. 


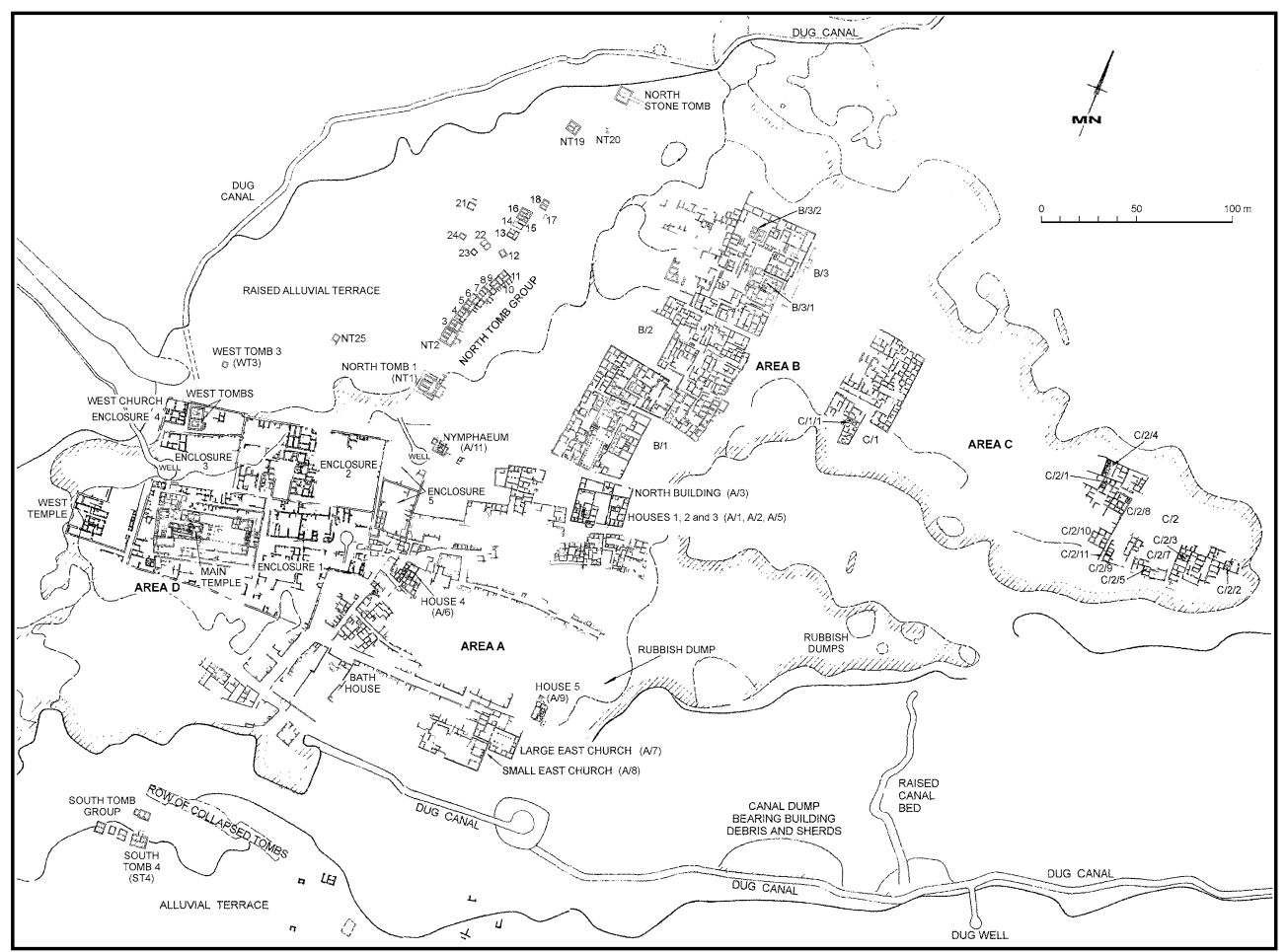

FIGURE 3 Map of Kellis

CREDIT: DAKHLEH OASIS PROJECT AND COLIN A. HOPE

wealth of some of Kellis' inhabitants in the third century. ${ }^{43}$ Enjoining Area B to the east is Area C. It was an early residential area, inhabited from at least the early second century until it was abandoned in the late third, and including many workshops and evidence for metal work. Its layout consisted of 'large areas of contiguous structures which comprise open courts flanked by smaller, rectangular rooms, most having been flatroofed. ${ }^{44}$ Finally, Area A is bounded by the Main Temple to the west and the B/1/1 complex to the north. It was mainly a residential quarter, although distinct from that of Area $\mathrm{C}$, consisting of separate housing blocks built in mud-brick, connected by alleyways and

43 Ibid., 207-9; Helen Whitehouse, 'A House, But Not Exactly a Home? The Painted Residence at Kellis Revisited', in Housing and Habitat in the Ancient Mediterranean: Cultural and Environmental Responses, ed. A. A. Di Castro, Colin A. Hope, and B. E. Parr (Leuven: Peeters, 2015).

44 Bagnall, Hope, and Worp, 'Family Papers', 229. See also Hope, 'Roman-Period Houses', 211. 
irregular thoroughfares. ${ }^{45}$ Two fourth-century churches were located in the south-eastern corner. In its northern part, bordering B/1/1, we find the domestic units House 1, 2, 3, and the small North Building, henceforth collectively referred to as the House $1-3$ complex. These are the main find-sites for papyri, and we examine them more closely in Chapter 3 .

\subsection{Its People and Their Livelihood}

In terms of population, Kellis fell far behind the two urban centres of Dakhleh, Trimithis and Mothis. Estimates of its size range from 500, at its low point, to 1500, at its zenith, probably in the third century. ${ }^{46}$ At the same time, its residents appear to have been comparatively affluent - indeed, Bagnall and Paola Davoli have remarked regarding the houses in Area B that ' $[t]$ he wealth suggested by these houses is beyond anything one would have expected in a village setting. ${ }^{47}$ Their wealth may, in part, have been derived from the particular climatic conditions of the Oasis, which facilitated the cultivation of crops that were difficult to grow in the Nile. Bagnall has argued that crops such as cotton and olives, in particular, but also figs, dates, and jujubes could be exported profitably from the Oasis to the Nile Valley. Alum, a valuable type of sulphate salts used in textile dyes, is attested in texts from Kellis. ${ }^{48}$

The village was abandoned in the late fourth or early fifth century. One might expect, then, that the fourth century saw a steep decline in its fortunes. Yet, it seems that Kellis remained a prosperous village well into this century. A declaration dated 357, P.Kellis I Gr. 15, mentions the appointment of as many as ten liturgists for collecting the chrysargyron, a tax on urban professionals like traders and artisans. Other papyri exhibit a variety of professions, most of which are also (or only) attested for the fourth century: carpenters, cobblers, potters, fullers, weavers, camel- and donkey drivers, well cleaners, bath attendants, scribes, a teacher, a bronze smith, a field guard, a geese keeper, a bed maker, and perhaps a honey seller.

Agriculture naturally held a prominent place. Here, too, the village seems to have been doing well in the mid-fourth century. Our best written source is the Kellis Agricultural Account Book (KAB), a wooden codex containing

\footnotetext{
$45 \quad$ P.Kellis $I V, 5^{-6 .}$

46 By Colin A. Hope and Anthony J. Mills in personal (separate) communications to J. E. Molto, 'Bio-Archaeological Research', 243. Bagnall, however, takes 1000 as a conservative estimate for the fourth century. P.Kellis $I V, 13$.

47 Roger S. Bagnall and Paola Davoli, 'Archaeological Work on Hellenistic and Roman Egypt 2000-2009', American Journal of Archaeology 115, no. 1 (2011): 140.

48 For cotton, see P.Kellis IV, 39-40; olives, 8o; for alum, see Wagner, Les Oasis d'Égypte, 3o69. See also Bagnall and Aravecchia, 'Economy and Society', $150-56$.
} 
an account of rents and expenses covering the years $361-64 .{ }^{49}$ It shows that Kellis functioned as a hub for surrounding hamlets. The author of the KAB was an estate manager, responsible for collecting rents from tenant farmers on behalf of a distant landlord: a certain Faustianos, son of Aquila, living in Hibis in neighbouring Khargeh Oasis. The manager had a storehouse in Kellis, and interacted with at least 138 named people, 36 of whom were regular tenant farmers. ${ }^{50}$ Even so, he was probably not responsible for all the landlord's holdings in the surroundings. And while some tenants apparently struggled to pay their dues, no general decline is obvious, although comparable material from earlier is admittedly lacking. ${ }^{51}$ Economic prosperity is suggested by other documentary texts from House 1-3. As we shall see in Chapter 3 (Section 3), these reveal a small workshop producing textiles for sale, and a private trading venture operating between the Nile Valley and the Dakhleh Oasis. Perhaps cotton gave these people a competitive advantage in exporting cloth, although cotton products are not mentioned explicitly in the letters, nor found in great quantities at the site. At any rate, their trading venture must be seen in light of Roman Egyptian commerce more generally. Egypt had an infrastructure conductive to trade: it experienced some degree of competition and mobility, and was extensively monetised (in comparative terms). ${ }^{52}$ Internal tolls were low. Goods manufactured in cities were sold in villages and vice-versa, trade being

49 Dated to indiction years $5-7$, probably covering the agricultural years $361 / 2,362 / 3$, and $363 / 4$, see P.Kellis $I V, 5^{8-59}$. Indiction years were used to date documents within 15 year-cycles, inaugurated during the reign of Constantine. Bagnall noted a four-year period in the following indiction cycle $\left(37^{-}-79\right)$ as a plausible (if less likely) alternative date for the book, but cf. Bagnall and Worp, 'Two 4th Century Accounts', 506-7.

$5^{\circ} \quad$ Based on the prosopography in P.Kellis IV, 63-72.

$5^{1} \quad$ For the manager's income, see ibid., $25^{-27}, 7^{6-8}$ o.

52 See Richard Alston, 'Trade and the City in Roman Egypt', in Trade, Traders and the Ancient City, ed. Helen Parkins and Christopher Smith (London: Routledge, 1998; repr. 2012); Dominic W. Rathbone, 'Roman Egypt', in The Cambridge Economic History of the Greco-Roman World, ed. Walter Scheidel, Ian Morris, and Richard Saller (Cambridge: Cambridge University Press, 2007); Matt Gibbs, 'Manufacture, Trade, and the Economy', in The Oxford Handbook of Roman Egypt, ed. Christina Riggs (Oxford: Oxford University Press, 2012). For the wider context, see the long-running debate between 'modernists' and 'primitivists' concerning the Roman economy. Central contributions include Moses I. Finley, The Ancient Economy (Berkeley: University of California Press, 1973); and Keith Hopkins, 'Taxes and Trade in the Roman Empire (200 B.C.-A.D. 40o)', The Journal of Roman Studies 70 (1980). While modernist positions have undergone substantial revisions, it has been maintained that 'recent research has increasingly pushed away from the "minimalist" end of the spectrum'. Walter Scheidel and Sitta von Reden, 'Introduction', in The Ancient Economy, ed. Walter Scheidel and Sitta von Reden (Edinburgh: Edinburgh University Press, 2002), 7. 
facilitated by the ease of transport on the Nile and, for the oases, by the Roman military presence providing roads and security. ${ }^{53}$

The sources even furnish us with prices for some common products, providing insight into daily life in Kellis in the mid - late fourth century. Below, two tables present a selection of prices and measures that appear in the papyri under discussion. Familiarity with prices and common measures is necessary in order to understand some passages quoted from these papyri, and to follow some of the arguments for dating actors and circles in Chapters 3 and 4. Prices did not remain static: the mid- and late fourth century saw both increasing price inflations and attempts at currency reform. ${ }^{54}$ Prices from before $c .355$, and after the late $370 \mathrm{os} / 38 \mathrm{os}$, therefore differed notably from those of the intervening period, making it to some extent possible to date documents based on monetary terms and prices, although it should be kept in mind that prices varied not only with time, but with locality and context as well. Table 1 lists measures in Roman Egypt, while Table 2 lists prices of different everyday items culled from the Kellis texts. 55

TABLE 1 Currency and measures in Dakhleh (c.355-370)

\begin{tabular}{|c|c|c|c|}
\hline Type & Measure & Equal to & Modern measure \\
\hline Currency & 1 talent $(\mathrm{T})$. & & \\
\hline Coin & 1 nummus & $c .1 \mathrm{~T}^{\mathrm{a}}$ & \\
\hline Coin & 1 solidus (sol.) & $c .8000-12$ o०o T. ${ }^{b}$ & $72 \mathrm{sol} .=323 \mathrm{~g}$ gold \\
\hline Weight & $1 \mathrm{mna}$ & $\begin{array}{l}c .1 \text { litra (Roman } \\
\text { pound) }\end{array}$ & $323 \mathrm{~g}$ \\
\hline Weight & 1 centenarion (cent.) & 100 litrai & $32.3 \mathrm{~kg}$ \\
\hline \multicolumn{4}{|c|}{ a See P.Kellis $V, 144$. } \\
\hline \multicolumn{4}{|c|}{$\begin{array}{l}\text { b The recently published O.Trimithis I } 19, c .35^{2-36 \circ} \text {, gives a price of } 7511 \mathrm{~T} \text {./sol. It fits well } \\
\text { with Bagnall's }(P . K e l l i s ~ I V, 57-59) \text { previous calculation of a mean of } 8000 \mathrm{~T} \text {./sol. for the KAB. } \\
\text { Against this, P.Kellis v Copt. } 11 \text { seems to place the worth of a solidus at } 11500 \mathrm{~T} \text {., although the } \\
\text { interpretation of the Coptic is uncertain, see } P \text {.Kellis } V \text {, } 59 \text {. P.Bingen } 120 \text {, dated } c .367 \text {, provides } \\
\text { a price of probably } c .12 \text { ooo T./sol.; Bagnall and Worp, 'Two } 4 \text { th Century Accounts', } 504-7 \text {. The } \\
\text { two latter probably relate to a slightly later period than the two former. }\end{array}$} \\
\hline
\end{tabular}

53 Colin Adams, Land Transport in Roman Egypt (Oxford: Oxford University Press, 2007), 91-115.

54 Roger S. Bagnall, Currency and Inflation in Fourth-Century Egypt (Chico: Scholars Press, 1985).

55 The information is partly drawn from P.Kellis $I V$, 47-54; and P.Kellis $V, 5^{8-65}$; and partly gathered from the papyri by the present author. 
TABLE 1 Currency and measures in Dakhleh (c.355-370) (cont.)

\begin{tabular}{|c|c|c|c|}
\hline Туре & Measure & Equal to & Modern measure \\
\hline Dry measure & 1 artaba (art.) & 10 mat. / 23 mat. & $\begin{array}{l}38.78 \text { litres }(30 \mathrm{~kg} \\
\text { wheat) }\end{array}$ \\
\hline Dry measure & $\begin{array}{l}1 \text { mation (mat.) - large } \\
1 \text { mation (mat.) - small }\end{array}$ & $\begin{array}{l}\text { 1/10 art. } \\
\text { 1/23 art. }\end{array}$ & $\begin{array}{l}3.88 \text { litres ( } 3 \mathrm{~kg} \text { wheat) } \\
1.69 \text { litre ( } 1.3 \mathrm{~kg} \text { wheat) }\end{array}$ \\
\hline Liquid measure & 1 chous & 6 sext. & 3.24 litres \\
\hline Liquid measure & 1 agon & 3 sext. & 1.62 litre \\
\hline Liquid measure & 1 sextarius (sext.) & & O.54 litre \\
\hline
\end{tabular}

TABLE 2 Selected prices in Kellis (c.355-70)

\begin{tabular}{|c|c|c|c|}
\hline Good & Amount & Value & Source \\
\hline Bread & 1 piece & 30 T. (Nile Valley) & P.Kellis v Copt. 21 \\
\hline Wheat & 1 art. & $1000-1500 \mathrm{~T}$. & P.Kellis v Copt. 15 , P.Bingen 120 , КАВ \\
\hline Barley & 1 art. & $500-1000 \mathrm{~T}$ & P.Kellis I Gr. 10, P.Bingen 120 \\
\hline Cotton & 1 lith. & $600 \mathrm{~T}$. & КАВ, P.Kellis I Gr. 61 \\
\hline Jujube fruits & 1 art. & $1500-2000 \mathrm{~T}$. & P.Kellis v Copt. 45, P.Kellis I Gr. 10 \\
\hline Olive oil & 1 sext. & $250-350 \mathrm{~T}$. & P.Kellis v Copt. 44 , P.Bingen $120, \mathrm{KAB}$ \\
\hline Papyrus & A pair $(?)^{\mathbf{a}}$ & $\begin{array}{l}\text { 100o-1200 T. } \\
\text { (Nile Valley) }\end{array}$ & P.Kellis viI Copt. 78 \\
\hline $\begin{array}{l}\text { Tunic } \\
\text { (stikharion) }\end{array}$ & 1 piece & $5000 \mathrm{~T}$. & P.Kellis v Copt. 26 \\
\hline Cowl & 1 piece & $1200-1300 \mathrm{~T}$ & P.Kellis viI Copt. $5^{8}$ \\
\hline Linen sheet & 1 piece & $2500 \mathrm{~T}$. & P.Bingen 120 \\
\hline Weaving wage & Per day & $6 \mathrm{o}-7 \mathrm{o} \mathrm{T}$ & P.Kellis v Copt. 48, 44 \\
\hline
\end{tabular}

a Presumably, the quantity was rather large: papyrus bought by Theophanes in Antioch earlier in the same century was not as expensive compared to other goods, see John Matthews, The Journey of Theophanes: Travel, Business, and Daily Life in the Roman East (New Haven: Yale University Press, 2006), 111. See also T. C. Skeat, "Was Papyrus Regarded as "Cheap" or "Expensive" in the Ancient World?', Aegyptus 75, no. 1/2 (1995). 


\subsection{Village Elites and Outside Influencers}

Naturally, village life involved differences in wealth and status, even if villages were often less hierarchical than cities. ${ }^{56}$ Kellis certainly had families with comparatively more wealth and power than others, as attested to by for instance the painted residence in Area B. Wealthier villagers would usually serve in important village liturgies, the office of komarch being the most prominent. In the mid-fourth century, Kellis had two komarchs, appointed by lots, as well as a village scribe who took care of record keeping and scribal work. ${ }^{57}$ However, notables and magistrates of the wider Oasis also wielded influence in Kellis, as evinced by the orders they sent to or (more often) petitions they received from locals. The Kellis papyri attest to both a logistes and an exactor, and even a deputy-exactor. ${ }^{58}$ As noted, these officials remained responsible for the entire Great Oasis into the fourth century. On the level of the Mothite Nome, we find papyri featuring council presidents, presumably of the city council in Mothis, and a praepositus pagi of Trimithis. ${ }^{59}$ An ex-magistrate ( $\left.\alpha_{p} \xi \alpha \varsigma\right)$ named Faustianos was petitioned in his capacity as 'defensor of the area', either the Mothite Nome or the whole Great Oasis. ${ }^{60}$ Such high personages usually resided in cities, not villages in the countryside. However, several papyri show that high-ranking magistrates had properties and strong ties to locals in fourth-century Kellis, and some of them may even have resided there. These are Gelasios, an ex-logistes, ${ }^{61}$ Pausanias, exactor and riparius, and an ex-magistrate of unknown office, Harpokration. They are treated more thoroughly in Chapter 4.

One important channel for their influence was landownership. Both Pausanias and Gelasios owned land in the village and/or its surroundings. Even a comparatively distant figure like Faustianos, the landlord of the КАВ who

56 For a short survey of empirical studies on landholding in the papyri see Roger S. Bagnall, Reading Papyri, Writing Ancient History (London: Routledge, 1995), 64-68. See also Ruffini, Social Networks.

57 See P.Kellis I Gr. 23, dated 352. Naphtali Lewis, 'Kleros, Komarch and Komogrammateus in the Fourth Century', Chronique d'Égypte 72, no. 2 (1997). For the scribe, see P.Kellis I Gr. 14, dated 356, and perhaps P.Kellis I Gr. 45, dated 382 (P.Kellis I, 136; but cf. P.Kellis IV, 63 and Lewis, 'Kleros', 346-47).

$5^{8}$ Note, respectively, P.Kellis I Gr. 25, P.Gascou 70, and P.Kellis I Gr. 23.

59 For the presidents, P.Gascou 72, P.Kellis I Gr. 25; for the praepositus, P.Kellis I Gr. 27. See. J. David Thomas, review of Greek Papyri from Kellis, I by Klaas A. Worp, ed, The Journal of Egyptian Archaeology 84 (1998): 262. For this praepositus, named Serenos, see now Bagnall and Ruffini, Ostraka from Trimithis.

6o For this question see P.Kellis I, 65-66 n.2.

61 For an early holder of this office, see J. David Thomas, 'The Earliest Occurrence of the exactor civitatis in Egypt (P.Giss. Inv. 126 Recto)', Yale Classical Studies 28 (1985). 
appears to have resided in Hibis in Khargeh, would have wielded influence on the local level through his landholdings. ${ }^{62}$ His managers ( $\pi p \circ v 0 \hat{\tau} \tau \alpha$ l) in Kellis collected rents and conducted other local affairs on his behalf. They were probably important men and women in their own right, themselves landowners of some stature locally, and their position would have been strengthened by ties to his large estate. ${ }^{63}$ Patronage was another way for elites to make their influence felt. Harpokration had villagers among his employees, one of whom came to him for protection against liturgical service and ended up causing a violent conflict in 353 . While elite influence extended down to the villagers, villagers could, in turn, take advantage of such influence for their own purposes.

This elite was not necessarily a force of stability: local feuds recur in several documents, ranging from familial to village-wide conflicts. ${ }^{64}$ Smaller conflicts naturally dominate, such as a house break-in and assault by a komarch, or a conflict over an inheritance between the children of an ex-magistrate. ${ }^{65}$ Two more wide-reaching conflicts are also documented. In one of them, escalation appears to have been averted. A declaration dated 352, P.Kellis I Gr. 24, shows that conflict had erupted between two men, one Ploutogenes and one Hatres. The exact complaint is unclear, as the body of the document is mostly lost,

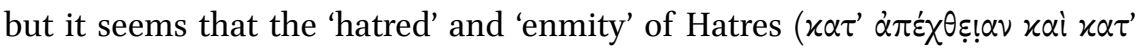

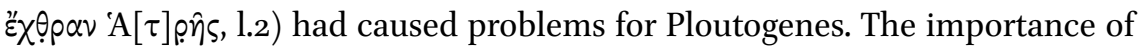
the conflict (or the influence of the alleged victim) is attested to by the fact that at least 33 men, three of them clergy, were recruited to participate as witnesses, swearing an oath that they had not known about Hatres' actions and that they would stay aloof from involvement. The declaration was to be sent to the $d u x$, i.e. the military governor, as surety, so that Ploutogenes would not suffer any further hardships. Such displays helped to restore unity and mutual trust - or at least the external projection of such - in the face of what might have become a damaging conflict.

Another large-scale conflict took place the year after, in 353, and this time it turned violent. As narrated in the petition P.Kellis I Gr. 23, it pitted two komarchs, Ploutogenes son of Ouonsis ${ }^{66}$ and a namesake and colleague, against

62 For the connection between Faustianos and Hibis, see now also Roger S. Bagnall and Gaelle Tallet, 'Ostraka from Hibis in the Metropolitan Museum of Art and the Archaeology of the City of Hibis', Zeitschrift für Papyrologie und Epigraphik 196 (2015): 189.

63 P.Kellis $I V$, 70-72. For women working as local managers, see ibid., 79-80.

64 For a criticism of the depiction of village elites as monolithic entities, see Giovanni Ruffini, 'Aphrodito before Dioscoros', Bulletin of the American Society of Papyrologists 45 (2008): 238-39.

65 P.Kellis I Gr. 21 and P.Gascou 69, respectively.

66 Probably to be identified with the man in P.Kellis I Gr. 24. See Chapter 4, Section 3.1. 
the ex-magistrate Harpokration. According to the petitioner, Ploutogenes son of Ouonsis, the conflict started when a villager named Taa refused to serve his allotted liturgy. He was apprehended by the komarchs, but Harpokration, his employer, sent several supporters (his son Timotheos ${ }^{67}$ and ten allies ${ }^{68}$ ) to attack the komarchs, stealing their goods and beating them severely. In turn, the komarchs mobilised supporters of their own. Harpokration's supporters were later disarmed, apparently without incident. As pointed out by Ari Bryen, it is difficult to assess the power balance between disputants, or the true course of events, based on the one-sided portrayal preserved in such petitions. ${ }^{69}$ At any rate, it vividly illustrates how village tensions could spill over into violence, and how local power brokers could be drawn into conflict with each other.

\subsection{Culture and Religious Life}

Graeco-Roman culture had made its way also to Kellis. Rhetors were active in fourth-century Dakhleh, and the evidence indicates that one may even have taught in Kellis, as a collection of speeches by the Athenian rhetor Isocrates $(436-338$ вСЕ), produced in the fourth century and perhaps used for teaching rhetoric, was found alongside the КАВ. ${ }^{70}$ Fragments of a Greek legend and of a verse composition echoing - possibly parodying - Homer have been found in the Main Temple. ${ }^{11}$

Our main interest here concerns the religious life of the village, which for much of its existence was dominated by the local temple cult. The main temple was dedicated to the divinities Tutu, his mother Neith, and his consort

67 Worp noted that '[i]t would seem slightly more attractive to assume that Timotheos is Harpokration's own son rather than a mere slave', P.Kellis I, 72. Ari Bryen, on the other hand, takes him to be a slave (Violence in Roman Egypt: A Study in Legal Interpretation (Philadelphia: University of Pennsylvania Press, 2013), 98); however, see the occurrence of a 'Timotheos son of Harpokration' in P.Kellis I Gr. 8 (ll.16-17).

68 Termed symmakhoi ( $\tau \hat{\omega} \nu$ $v \mu \mu \alpha \dot{\alpha} \chi \omega \nu, 1.23$ ). Bryen takes them to be assistants of the riparius; if so, we may here actually be dealing with a conflict between nome and village administration. Bryen, Violence in Roman Egypt, 98.

69 Ibid., 98-10o.

70 Olaf Kaper, 'The Western Oasis', in The Oxford Handbook of Roman Egypt, ed. Christina Riggs (Oxford: Oxford University Press, 2012), 725; Pasquale M. Pinto, 'P. Kellis III Gr. 95 and Evagoras I', Zeitschrift für Papyrologie und Epigraphik 168 (2009). Note also P.Kellis I Gr. 53 (l.2).

71 Colin A. Hope and Klaas A. Worp, 'Miniature Codices from Kellis', Mnemosyne 59, no. 2 (2006); Klaas A. Worp, 'A Mythological Ostrakon from Kellis', in The Oasis Papers 3: Proceedings of the Third International Conference of the Dakhleh Oasis Project, ed. Gillian E. Bowen and Colin A. Hope (Oxford: Oxbow, 2003). 
Tapsais or Tnaphersais, 'great and powerful gods of the village of Kellis.' ${ }^{2}$ Tutu (also called Tithoes) often took the form of a sphinx; he had become popular in Egypt as the chief of a demonic army, being often titled 'master of demons.' ${ }^{73}$ An example of personal piety to these gods has been discovered in the form of a votive statue dedicated by Talaous, daughter of Thaesis. ${ }^{74}$ The name Tithoes was moreover one of the most popular male personal names in the village beaten only by $(\mathrm{P})$ shai, the personification of an individual's 'luck', 'fate', or 'daemon'. Of other gods, we find that Seth, whose main cult-centre was located in Hibis, also received worship in Kellis. ${ }^{75}$ Isis was a popular goddess in the Great Oasis in the form of Isis-Sothis or Isis-Demeter: a third-century dedi-

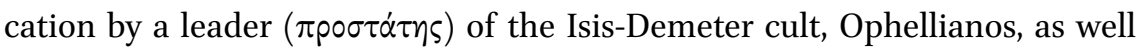
as two statues of the goddess, have been found in Kellis. ${ }^{76}$ Ophellianos' title shows the existence of a cultic association dedicated to her, and it has been suggested that the large painted residence in Area $\mathrm{B}(\mathrm{B} / 3 / 1)$ could have housed the meetings of such a cult. ${ }^{77}$

Excavations of the Main Temple indicate that it was in continued use into the early fourth century, and ostraka found here attest to the activities of its priests and other worshippers. A man named Psais inhabited the important

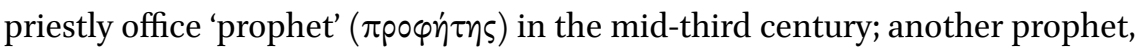
Pachoumis, was active later in that century. ${ }^{78}$ A group of temple attendants ( $\pi \alpha \sigma \tau 0 \pi \dot{\rho} \rho \circ)$ are listed in O.Kellis I 98 , an account of oil arrears from the years 299, 300, and $302 .{ }^{79} \mathrm{~A}$ man called Psais the potter was a leading priest at the end of the third century; he was still alive in 294 (O.Kellis I 145), but had died

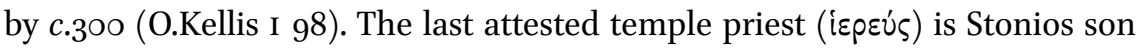
of Tepnachthes, who witnessed a contract in the year 335, P.Kellis I Gr. 13. The

72 For this title, and for the temples and priests of Kellis, see Kaper, Temples and Gods, 27-40, $87-138$.

73 David Frankfurter, Religion in Roman Egypt: Assimilation and Resistance (Princeton, NJ: Princeton University Press, 1998), 115-16.

74 Klaas A. Worp and Olaf Kaper, 'A Bronze Representing Tapsais of Kellis', Revue d'Égyptologie 46 (1995); Frankfurter, Religion in Roman Egypt, 115-16.

75 Kaper, Temples and Gods, 55-64; Frankfurter, Religion in Roman Egypt, 113. A man with the rare theophoric name Seth appears in O.Kellis I 123.

76 Hope and Worp, 'Dedication Inscription'; Olaf Kaper, 'Isis in Roman Dakhleh', in Isis on the Nile: Egyptian Gods in Hellenistic and Roman Egypt. Proceedings of the IVth International Conference of Isis Studies, Liège, November 27-29 2008, ed. Laurent Bricault and Miguel John Versluys (Leiden: Brill, 2010).

77 Whitehouse, 'A House', 252-53.

78 See Worp, 'A New Wooden Board'; id., 'Short Texts'.

79 The pastophoroi were tasked with carrying sacred objects in processions and other minor duties (such as guarding the temple). Bowman, Egypt after the Pharaohs, 182. 
great temple building appears to have gone out of use as a place of worship around this time.

Jewish names, e.g. Mouses, Elias, and Rachel, are known from Kellis, although they are unlikely to indicate the presence of a Jewish community, but probably refer to Christians. ${ }^{80} \mathrm{~A}$ Christian community must have been active already by $c .300$, as indicated by the three churches that appeared in the first half of the fourth century. The earliest of them, the Small East Church, dates from the reign of Constantine. The other two, the Large East Church and the West Church, were built shortly thereafter, in the second quarter to mid-fourth century. ${ }^{81}$ Panels of coloured glass, perhaps decorated with religious motifs, were found in the Large East Church, evincing a wealthy community around this time. Evidence for Christian presence in the period prior to this is scarce, however. ${ }^{82}$ The first clear evidence comes shortly after the last appearance of the pagan priest Stonios, when in 337 a certain Harpokrates, 'priest of the

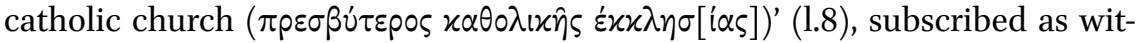
ness to a contract, P.Kellis I Gr. 58. The expression 'catholic church' occurs altogether three times in the House 1-3 material, each time in connection with the title of an office. ${ }^{83}$ P.Kellis I Gr. 58 is the earliest, and an early attestation for this expression in the papyri in general. Another priest of the 'catholic church'

8o P.Kellis I, 163. In general, however, the onomastics of Kellis do not seem to tell us much about religious change. Worp's analysis concludes that there is comparatively little in the Kellis onomasticon to indicate 'Christianisation'. See Klaas A. Worp, 'Christian Personal Names in Documents from Kellis (Dakhleh Oasis)', Zeitschrift für Papyrologie und Epigraphik 195 (2015); for the debate regarding naming trends and religious change, see Roger S. Bagnall, 'Religious Conversion and Onomastic Change in Early Byzantine Egypt', Bulletin of the American Society of Papyrologists, no. 19 (1982); Ewa Wipszycka, 'La valeur de l'onomastique pour l'histoire de la christianisation de l'Egypte. A propos d'une étude de R. S. Bagnall', Zeitschrift für Papyrologie und Epigraphik 62 (1986).

81 Gillian E. Bowen, 'The Fourth-Century Churches at Ismant el-Kharab', in Dakhleh Oasis Project: Preliminary reports on the 1994-1995 to 1998-1999 Field Seasons, ed. Colin A. Hope and Gillian E. Bowen (Oxford: Oxbow, 2002).

82 Two almost identical contracts dated 319 and 320 , P.Gascou 18 and 19, pertaining to a trade-venture to the Nile Valley, use the expression 'with god' ( $\sigma \dot{\nu} v \theta \varepsilon \hat{\omega})$, often taken to indicate Christian belief. This assumption is not unproblematic; see Malcolm Choat and Alanna Nobbs, 'Monotheistic Formulae of Belief in Greek Letters on Papyrus from the Second to the Fourth Century',Journal of Greco-Roman Christianity and Judaism 2 (20012005): 40-41; Choat, Belief and Cult, 104-5. However, one of the men is named Ouonsis, a figure that also features (if likely as a patronym) in the context of a 'presbyter of the catholic church' in P.Kellis I Gr. 24.

83 Worp counts four (P.Kellis I, 74), but the last, a Psekes found in P.Kellis I Gr. 48, is not described as $\varkappa \alpha \theta_{0} \lambda \iota x \hat{\varsigma} \varsigma$. For the expression 'catholic church', see Ewa Wipszycka, 'Katholiké et les autres épithètes qualifiant le nom ékklesía: contribution à l'étude de l'ordre, hiérarchique des églises dans l'Égypte byzantine', The Journal of Juristic Papyrology 24 (1994). 
was involved in the dispute between Ploutogenes and Hatres in P.Kellis I Gr. 24, dated 352. Finally, P.Kellis I Gr. 32, dated 364, features a 'reader of the catholic

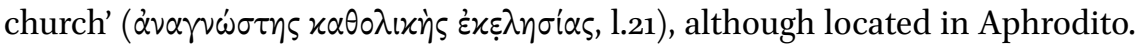
Use of the term 'catholic church' may reflect a distinction between different church communities in the village. Thus, a few Sahidic Coptic letters from House 4 and D/8, published in P.Kellis VII, may pertain to adherents of a 'mainstream' Christian Church existing alongside a Manichaean one, as we shall see.

\section{$4 \quad$ Oasis Society and Religious Movements}

The first evidence for Manichaeans in Kellis is contemporary with the evidence for 'catholic' officials, i.e. the 330s, although the movement must have arrived in the Great Oasis earlier. We return to its spread, growth, and interaction with other religious communities in the village in Chapter 6 . The concluding discussion here is more impressionistic, confined to general remarks concerning aspects of Oasis society that may have affected the way Manichaeism extended its reach from the Nile Valley to the Oasis. Two such attributes stand out as possibly consequential for the spread of religious communities in the Oasis: its centralised elite and its mobile inhabitants.

A common way for network researchers to conceptualise the spread of religions is to see them as information flows within networks of actors of varying centrality. ${ }^{84}$ In centralised societies, information has to flow through a relatively limited set of people. The natural environment of the Oasis necessitated a degree of spatial and social centralisation, as we have seen. Agricultural organisation was more strictly hierarchical here than elsewhere in Egypt, due to the investments of labour and resources needed to develop new plots of land. The author of the KАВ reported to a landlord living all the way over in Hibis in Khargeh. Political centralisation is also evident, considering that the chief officials of the Roman administration were responsible for both Khargeh and Dakhleh.

The Great Oasis, then, seems to have had a rather narrow group of decisionmakers, both administrative and economic. The influence held by such a centralised elite will have affected how religion spread to and through the Oasis. It could be argued that this made it more difficult for new religious movements to enter, as the social status and conservatism of the political elites might make

84 See for instance Anna Collar, 'Network Theory and Religious Innovation', Mediterranean Historical Review 22, no. 1 (2007); Woolf, 'Only Connect?'. 
them less amenable to social and/or religious deviation..$^{85}$ On the other hand, they would also have been more frequently exposed to new ideas or trends from the Nile Valley than other inhabitants. Moreover, such centralisation can quickly become a boon to religious movements if they manage to elicit support from central figures in the network of power. The sudden appearance of churches all over Dakhleh in the first half-to-mid fourth century suggests that this centralisation at any rate did not constitute a barrier to the spread of Christian (and/or Manichaean?) communities.

Another feature of Oasis society may have contributed to this spread, however, namely the high degree of mobility of parts of its population. Mobility in the antique world, the physical movement of people and goods, has recently seen increased scholarly interest. ${ }^{86}$ Manichaeism, as a religious movement, has often been ascribed a particularly high degree of mobility, through the itinerancy of its Elect and its affiliation with trade communities. A high degree of mobility was characteristic of certain groups within Oasis society as well. No Nile River provided easy transportation. A comparatively large segment of the population therefore had to be engaged in the overland movement of goods, which according to Bagnall may have offset the stark hierarchy, since " $[t]$ here were a lot of onelatai, donkey drivers, and kamelitai, camel drivers, in the oases, far more than in most Valley communities. ${ }^{187}$ These did not only work within the Oasis itself, but served the need and desire of Oasites for contact with the Nile Valley. In turn, this may have given such groups a more prominent place in the Oasis than in Egypt at large. It can be no coincidence that the people most closely associated with Manichaeism in Kellis were also deeply engaged in the Nile Valley-trade, as we shall see.

85 See the arguments in Collar, Religious Networks, 19-20.

86 The topic has attracted attention at least since Lionel Casson, but has recently seen an uptick. A landmark study is Peregrine Horden and Nicholas Purcell, The Corrupting Sea: A Study of Mediterranean History (Oxford: Blackwell, 200o). For a collection of both empirically and theoretically oriented studies of the Roman Empire, see Luuk de Ligt and Laurens E. Tacoma, eds., Migration and Mobility in the Early Roman Empire (Leiden: Brill, 2016). A recent study of physical mobility in Egypt is Adams, Land Transport. For a study concentrating on long-term patterns of movement in the Oasis, see Boozer, 'The Social Impact'. For movement in relation to cult in particular, see Simon Price, 'Religious Mobility in the Roman Empire', The Journal of Roman Studies 102 (2012); Philip A. Harland, ed. Travel and Religion in Antiquity (Waterloo: Wilfred Laurier University Press, 2011). 